\title{
Impact of Corporate Governance index on Firm Performance: evidence from Pakistani manufacturing sector
}

\author{
Faisal Javaid (Corresponding author) \\ School of Business and Management Sciences \\ University of Gujrat, Sialkot Sub Campus \\ Tel: +92-300-6052772Ｅ-mail: Faisal.javed@uogsialkot.edu.pk
}

\begin{abstract}
Abdul Saboor
Chenab College of Advanced Studies, Faisalabad

Tel: +92-321-9660123 E-mail: Saboorfsd@ hotmail.com
\end{abstract}

Accepted: April 17, 2015

Doi:10.5296/ jpag.v5i2.7498 URL: http://dx.doi.org/10.5296/ jpag.v5i2.7498

\begin{abstract}
Corporate governance is considered to have significant impact on the growth and development perspective of an economy. Sound corporate governance practices leads the economy towards the achievement of higher performance, provide sources for capital investment by increasing the creditability of shareholders. The purpose of this study is to empirically investigate the relationship of corporate governance and firm performance in terms of accounting as well as market performance i.e.to be measured by Return on asset, Return on equity and Tobin's Q. The theoretical base to conduct the study is the demand of separation of ownership and control characterize as agency theory. The previous studies have yielded inconsistent result. To achieve the purpose 58 manufacturing sector companies were selected listed in the Karachi stock exchange and data was taken from annual reports of the companies for the period of 2009 to 2013. Descriptive statistics, correlation analysis and regression estimation using pooled, fixed effect, random effect and Hausman specification test were carried out after developing a composite index based on 21 proxies. The result entails that corporate governance index (CGI) and firm performance has positive and significant association but the relationship for each specific index is dependent upon the measure of firm performance. The result also shows that companies having strong corporate governance mechanism has greater chances to acquire finance. The implication of study
\end{abstract}


demands that the reform effort should be directed towards the improvement in internal corporate governance mechanism and regulatory framework for the governance system.

Keywords: Corporate Governance, Tobin's Q, Performance, ROA.

\section{Introduction}

International financial world is facing rapid changes in terms of financial as well as economic systems. These systems have been upsetting from years. In this era the introduction of new technologies in both services and product industry around the globe has created issues to govern the global environment. All these circumstances have forced the countries to adopt a sound system of corporate governance which enable them to survive in dynamic and open environment of innovations. Similarly Bertrand Russell said that "the beggars can never be envious of millionaires, but there is no doubt that they can envy the other beggars who are not making success". Russell's remarks throw light that the same condition will be hold in a firm if the shareholders having same position in a firm are discriminated. Due to this fact the conflict between management and shareholders exist. Corporate governance introduces various solutions to align the management activities for the benefit of shareholders in all working areas of the corporation. The definition of the corporate governance depends upon the perspective of the onlooker. It has a large concern with cultural environment and perspective of researcher. Corporate governance is a system of laws, rules and elements that control the activities of a firm.(Gillan\& Starks, 1998) Corporate governance refers to the procedures and mechanism which direct the business affairs which leads the firms towards corporate performance that ultimately bring enhancement in the value of shareholders equity and their accountability(Jenkinson\& Mayer, 2012).Corporate governance builds the credibility, assures transparency to maintain accurate disclosure of facts and figures and brings the corporate accountability that results to improve the overall performance of firm.

Corporate governance is concerned with the defense of the investors. With the help of governance mechanism the interest of shareholders is protected.(Johnson \& Greening, 1999).Corporate governance is the way through which minority shareholders safely guard their interest against the confiscation of management and controlling shareholders. Corporate governance refers to a complex set of mechanisms that helps to ensure the investors that they are gaining fair return on their investment.(A. Shleifer\&Vishny, 1997).

The managers and shareholders of firms as well as stakeholders are governed by laws and regulations which are offered as corporate governance which increases the financial stability and growth of the firm through reinforcement of integrity, confidence and efficiency. (OECD 2004). According to Gomez the management is defined as a mechanism of organization who work towards he achievement of efficiency and objectives in term of the firm and governance is the mechanism to achieve the objectives achievement in the interest and terms of the shareholders who have invested their money.(Van Den Berghe\& De Ridder, 1999).

Good governance increases the corporate performance and accessibility of external finance that brings the sustainable economic growth. It creates bond among the management, Board, 
stakeholders, controlling and minority shareholders. It serves a number of goals like reducing the effect of financial crises; strengthen the rights over property, results in decreasing cost of doing business and of capital which leads the market towards development. The firms requiring more external finance can have advantage of adopting good corporate governance that can lessen the cost of capital that is why they have better tendency to adopt corporate governance practice and it will increase the believe of insiders by increasing the firm value and the likeness of shareholders. It will put positive influence on the shareholders and will increase the access to external finance.

With the introduction of code of corporate governance to govern the listed companies of Pakistan in 2002 by SECP, the area of corporate governance has got importance and the researchers are making new ground in this regard. Through corporate governance it is determined that who are the owners of the company as well as the regulations through which the earnings of firm are distributed among the investors, managers and other stakeholders.(La Porta, Lopez-de-Silanes, Shleifer, \&Vishny, 2000).In broad context corporate governance is refers to a modern-day governance system which looks after the interest of shareholders of the firm by establishing the legal, social and economic institution.

Corporate governance throws lights on number of issues with main focus on the association between owners. Board, top management, and CEO and in addition compensation paid to the executives. (Keasey, Thompson, \& Wright, 2005). Board structure (Sheikh \& Wang, 2012), proportion of outside directors (Su \& He, 2012), CEO duality (Bokpin\&Arko, 2009 , board meeting (Birdsall, Vyas, Khazaezadeh, \&Oteng-Ntim, 2009), directors remuneration(Sheikh \& Wang, 2011), ownership structure (Fama\& M. C. Jensen, 1983), transparency and disclosure (Antwi\&Binfor, 2013) and audit related committee (Lin \& Chang, 2012) are seemed to have significant influence on the relationship of corporate governance and firm performance. This study is aimed to explore the association between the corporate governance and firm performance of manufacturing sector companies of Pakistan listed in the Karachi stock exchange. The elements affecting the governance practices have been summarized in the form of corporate governance index which is composite of three sub indexes. This index will pin point that whether corporate governance practices increase firm performance and which index or element is more important for improving the firm performance which is to be measured through financial and accounting measure i.e. return on asset, return on equity and Tobin's Q.

Various previous studies have used only one or two regression in determine the relationship between Corporate Governance and firm performance by ignoring the complexity of dimensions. This study is based on using the secondary data from the annual reports of the listed companies in Pakistan and the use of various model and panel data technique. The short coming of previous studies will be eliminated in this critique. In this study panel data technique have been employed which includes random and fixed effect regression model as well as the correlation matrix. A self constructed composite index will be developed for the manufacturing firms of Pakistan to overcome the previous studies deficiencies. 


\section{Corporate governance Indicators}

Various mechanism of corporate governance is introduced in order to pursue the management to act in the best interest of the investors. These mechanisms may be of internal or external nature. Internal mechanism of corporate Governance includes the board size, board meeting proportion of outside directors. Director's remuneration, ownership structure, audit related committee and disclosure and transparency. The external mechanism may include the anti take over, acquisition labor and maker related laws.

This study is directed towards corporate Governance internal mechanism. Following are the dimensions that seem to have a significant impact on a firm performance.

\section{Board Size}

The board of director is the highest decision making body of a company. The board is aim to provide guidance for ensuring good performance and to maximize shareholders worth. It has the responsibility to monitor and instruct the senior management. (Sheikh \& Wang, 2012).

\section{Outside Directors}

Outside directors as compared to other dependent board have more insight and knowledge so they can influence the practice of corporate governance. The results on definite percentage of Outside directors of a firm, Proxy board members and performance of an organization is questionable. It was proposed that a positive relation exist between the presence of outside directors and stock market feedback .(Brickley, Coles, \& Terry, 1994).

\section{Board Meeting}

To measure the effectiveness of board number of meetings conducted in a year can be used.It has been proved by researcher that those firms have less problems related to the management earnings which arrange frequent number of board aid audit committee meetings.(Xie, Davidson, \& DaDalt, 2003).

\section{CEO Duality}

CEO duality exists when same person is Chief Executive officer and chairman of a firm. Due to this financial decision of the firms affected and results in creating agency problems. Therefore it is suggested that both positions should not be held by the same person. However, mixed results have been provided by various researchers in this regard. Firms have more importance in the marker which have separate of CEO and chairman.(Yermack, 1996).

\section{Director's Remuneration}

The compensation committee proportion and existence have significant relationship with the management and board remuneration.(Murphy \& Jensen, 1998).

\section{Ownership structure:}

Various empirical researches provided evident in favor of agency theory that determines that management on behalf of the shareholders may take decisions that may be unpredictable 
to maximize shareholder's capital(Fama \& M. C. Jensen, 1983).

\section{Disclosure and transparency}

Transparency is the availability of the truth to others. This does not only means to provides the truth but also includes telling it to the shareholders which means perfect and complete disclosure.(Antwi \& Binfor, 2013)

\section{Audit related committee}

The purpose is to increase the truth worthiness of the financial reports by auditing of financial statements. This committee refers to the audit committee. The member of committee reviews the financial statement at regular interval. it has also been argued that the independent director and audit committee have positive association with firms performance .(Lin \& Chang, 2012).

\section{Research Methodology}

This study is aimed at to provide evidence on association between the corporate governance and performance of manufacturing sector firms. This section sheds light how panel data techniques and different methodologies are used to determine the relationship between corporate governance and firm performance. By using the secondary data from the annual reports of the sample companies this study analyzed the relationship between Corporate Governance and firm performance by using research tools to support the literature.

\subsection{Summary of Prior Methodologies}

The methods used for measuring corporate governance and firm performance are inconclusive. The previous research which is on hand having yield mixes results. An inconsistent measuring approach has been used by the researchers. They used various methodologies in this regard. Some researchers used cross sectional data(L. Brown \& Caylor, 2004). Other used portfolio approaches (Bauer, et al., 2008) .

Different regressions models like ordinary Least square (B. S. Black, et al., 2006), (Klein, et al., 2005)Estimated Generalized least Square (Hussain \& Mallin, 2003) and Pearson and spearman Correlation (L. D. Brown \& Caylor, 2009) and Generalizes method of Moments (Javed \& Iqbal, 2010)have also been used in previous research.

\subsection{Sample size}

To study the level of compliance of corporate governance for the manufacturing sector firms the sample size of 58 manufacturingsector firms have been selected on the basis of the availability of data. Time Span of the Study

In this research the secondary data is utilized which is obtained from the annual reports of the manufacturing sector firms listed in Karachi Stock Exchange from the year 2009 to year 2013. These reports are acquired from the websites of the companies and official site of Securities and Exchange Commission of Pakistanand from Lahore Stock Exchange. 


\section{Macrothink

\subsection{Models for Research}

MODEL (1)

PERF $_{\text {it }}=\beta+\beta_{1}$ CGI $_{\text {it }}++\beta_{2}$ SIZE $+\beta_{3}$ LEV $+\beta_{4}$ INV $_{\text {it }}+\varepsilon_{\text {it }}$

MODEL (2)

PERF $_{\text {it }}=\beta+\beta_{1}$ BOD $_{\text {it }}+\beta_{2}$ OWN $_{\text {it }}+\beta_{3}$ DISCL $_{\text {it }}+\beta_{4}$ SIZE $+\beta_{5}$ LEV $+\beta_{6}$ INV $_{\text {it }}+\varepsilon_{i t}$

MODEL (3)

$\mathrm{EF}_{\mathrm{it}}=\beta+\beta_{1} \mathrm{CGI}_{\mathrm{it}}+\beta_{2} \mathrm{SIZE}+\beta_{3} \mathrm{LEV}+\beta_{4} \mathrm{INV}_{\mathrm{it}}+\varepsilon_{\mathrm{it}}$

\section{Abbreviation used in Models}

PERF $=$ performance

$\mathbf{I}=$ manufacturingcompany

$\mathbf{t}=$ year

$\boldsymbol{\beta}=$ parameters to be estimated

$\mathbf{C G I}_{\mathbf{i t}}=$ aggregate score of Corporate Governance index

BOD $_{\text {it }}=$ score of sub index 1 board structure

$\mathbf{O W N}_{\mathrm{it}}=$ score of sub index 2 ownership structure

DISCL $_{\mathbf{i t}}=$ score of sub index 3 disclosure

$\mathbf{S I Z E}_{\mathbf{i t}}=$ logarithm of total assets

$\mathbf{L E V}_{\mathbf{i t}}=$ long term debt to total assets

$\mathbf{G R O}_{\text {it }}=$ market value to book ratio

$\mathbf{I N V}_{\mathbf{i t}}=\log$ arithm of Average Sales Growth

$\mathbf{E F}_{\text {it }}=$ External Finance

In this study the corporate governance index is based on the 21 proxies listed in three categories known as sub index named as BOD, OWN and DISC. Equal weights to each sub index has been assigned .Aggregate CGI score is generated by taking the average score of all these three sub indices for each manufacturingfirm which indicates its corporate governance practice. The detail of three sub indices is as follows:

\section{Sub index 1: Board Structure}

Board is regarded as a core factor of Corporate Governance(Dahya, Dimitrov, \& McConnell, 2008). It was reported that board is the first indicator which has the ability to have impact on 


\section{Macrothink}

the management and their behavior but if managers have domination on the board then this will not hold true.(Bai, et al., 2006).Board is regarded as measure of internal corporate governance. As board are selected on the basis of political and administrative process so they have less ability to monitor the management so it is an important issue to see whether they effect the corporate governance practices or not.

\section{Board Size}

II. Proportion of Outside Director

III. Proportion of Executive Director

IV. CEO Duality

\section{Number of Board Meetings}

VI. Effectiveness of Board Meetings

VII. Existence of CFO

\section{Sub Index 2: Ownership structure}

It was reported that the cash flow rights and voting power rights are considered to have lower down the firm value .such firms are unable to protect the minority shareholders and their rights are expropriated. So ownership structure should create a lodge between these two.(Claessens, et al., 2002; La Porta, et al., 2000) The presence of inside voting shares that are common stock holders and outside holdings like preferred share is a good mechanism to create wedge between economic and voting rights..
I. Presence of block holders
II. Ownership Concentration
III. Managerial ownership
IV. Director ownership
V. Family Ownership

VI. Institutional ownership

VII. Percentage of voting shares with controlling shareholders

\section{Sub Index 3: Disclosure}

Studies have shown the sub index of disclosure has positive correlation with firm performance (Durnev \& Kim, 2005). Similarly (A. Klein, 2002) reported that firm having greater disclosure leads the company towards the generation of high value. In this study six elements of disclosure are taken which are as follows:

I. Disclosure of Corporate Governance practices

II. Disclosure of remuneration 
III. Audit related committee

IV. Disclosure of shareholding categories

V. Disclosure of Executive member Ownership

VI. Availability of financial report on websites

VII. Audit Related Committee

\section{External Financing}

The firms who depend upon external finance show higher performances. The legal security to investor is highly associated with the raising of external financing whether it is equity or debt.(Iqbal, et al., 2006). Poor enforcement of law is a strong obstacle in gaining position in stock market. The sources to raise external finance not only depend on corporate governance changes but also on the institutions which set standard. Protective and legal laws as well as on the condition of stock market where investor pursue for better returns .(Patrick, 2001).

\section{Financial Performance}

The firm performance can be measured by using various formulae. These measures can be categorized into market based and accounting based measures.(A. Klein, 2002). From the perspective of accounting based measure ten famous and easier way to calculate firm performance is ROA as used by(Kiel \& Nicholson, 2003) and ROE as used by (Baysinger \&Butler, 1985)and earnings per share. On the other hand from the perspective of market based measure Tobin's Q i.e. ratio of market value to book value (Barnhart, et al., 1994).

\section{Analysis, Results and Discussions}

To analyze the association of corporate governance with firm performance and need of external finance quantitative data techniques has been employed. Independent variable i.e. corporate governance is measured by CGI index divided into three sub indices is calculated on the basis of compliance of code of corporate governance, external finance and dependent Variable i.e. ROA, ROE and Tobin's Q with control variable size, leverage and investment has been used in formulation of research models .Depending upon the secondary nature of data unit root test is also applied to check the stationary nature of data. Analysis techniques are based on descriptive statistics and estimation through regression models. To check the association among all variables correlation analysis is applied and results are shown through correlation matrix. 
Table 1: Descriptive Analysis

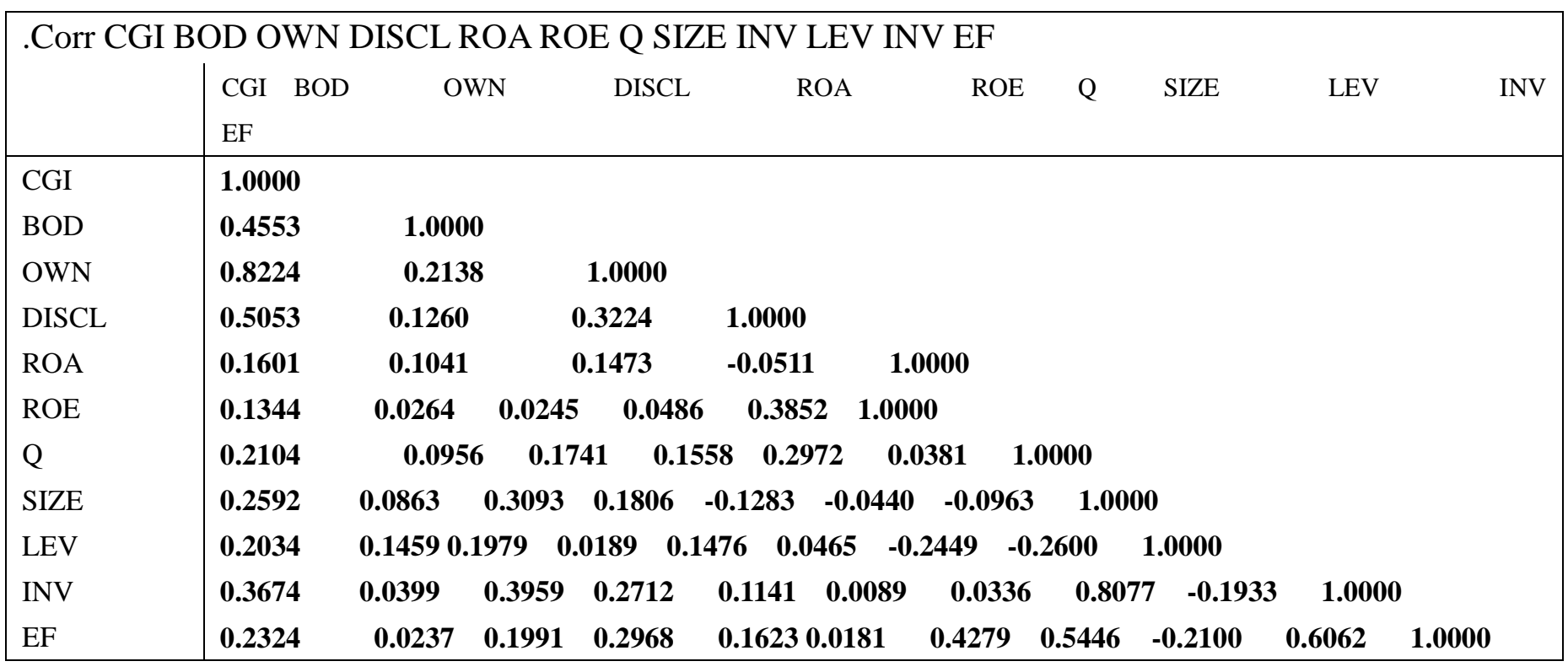

Descriptive results indicate that score of corporate governance index for manufacturing sector firm ranges from 53.8095 to 81.4286 with average rating 70.1164 . The minimum score of sub index $\mathrm{I}$ is 50 and maximum score is 83.4432 and average score of 72.57143 .These ratings shows that the board structure of manufacturing firms of Pakistan includes firms having strong board control having effectiveness as well as firms having less control with less autonomy. The maximum score for sub index II is 89.5714 with minimum score 18.5714 and average score is 60.1111. It means that the Pakistani manufacturing firms are characterize with higher concentration of ownership and presence of block holder where voting power is controlled by top $10 \%$ shareholders. The sub index III disclosure and transparency has range of score from 60 to 88.6755 and average score of 77.6666 which shows that the firms do fair disclosure in the annual reports and to their shareholders and do compliance with the SECP rules and Code of corporate governance. On the part of need of external finance the average score is 8.662184 and score range is 7.230449 to 10.32222 . This figure shows that the sample firms have need of external finance which is dependent on the corporate governance mechanism. These firms have sound corporate governance practices have more sources to raise finance.

Correlation matrix indicates that a positive relationship exist between corporate governance and performance measures i.e. ROA, ROE and $\mathrm{Q}$ having $\mathrm{r}$ value $0.16,0.13$ and 0.21 the firms which have strong and sound corporate governance structure can be more productive and efficient in respect of profits and output.

The sub index 1 and firm performance have positive association with each other which indicates that firms having larger board structure, more independent directors, executive directors, holding frequent meetings and having effectiveness of board, avoiding CEO duality and having $\mathrm{CFO}$ chair can perform better and have sound implementation of corporate governance practices. These results are supported by

The sub index II of ownership structure and performance measures also have positive 
relationship which implies that firms having family ownership and managerial ownership with less ownership concentration having block holders are directed towards the better performance as indicated by value of $r$.

The sub index III of disclosure and transparency and performance measures with $r$ value of 0.53 is having positive relationship with performance indicators. It means firms having fair, accurate and audited disclosures are more profitable and are ableto satisfy their shareholders.

The relationship of external finance and corporate governance is also positive which shows that firms which have sound practices of corporate governance have more sources $t$ raise furnace through debt and equity. The value of $r$ is 0.23 which shows the relationship of corporate governance and external finance.

Fisher Type Panel Data Unit root test is used to check the stationary nature of data. It is based on Augmented Dickey-Duller (ADF).

\section{Table 3: Unit Root Test}

\section{Fisher Type unit Root Test \\ Based on augmented Dickey-Fuller tests}

Ho: All panels contain unit roots

Ha: At least one panel is stationary

Number of panels $=58$

AR parameter: Panel-specific

Number of periods $=$

Panel means: Included

Asymptotic: T -> Infinity

Time trend: Not included

Drift term: Not included

ADF regressions: 0 lags

\begin{tabular}{|c|c|c|}
\hline Variables & P-value & Statistics \\
\hline BOD & 0.0000 & 141.8109 \\
\hline OWN & 0.0000 & 124.8124 \\
\hline DISCL & 0.0000 & 107.5312 \\
\hline CGI & 0.0000 & 168.1614 \\
\hline ROA & 0.0000 & 96.9473 \\
\hline ROE & 0.0000 & 225.6886 \\
\hline Q & 0.0000 & 187.9708 \\
\hline SIZE & 0.0000 & $\mathbf{8 1 . 9 0 0 9}$ \\
\hline LEV & 0.0000 & 360.8686 \\
\hline INV & 0.0000 & 498.0878 \\
\hline EF & 0.0087 & 41.1038 \\
\hline
\end{tabular}

The figures of P-value are less than $\boldsymbol{\alpha}(0.05)$ for all the variables so we reject $\mathbf{H}_{\mathbf{0}}$.The assumption before the estimation of regression model is fulfilled i.e. all the variables are stationary which shows that variables are not dependent over time. It is also concluded that 
data does not have any unit root at zero lag with no time and no drift trend.

\section{Regression Analysis}

Relationship of corporate governance and firm performance using ROA as performance indicator

\section{Results for model (1)}

PERF $_{\text {it }}=\beta+\beta_{1}$ CGI $_{\text {it }}++\beta_{2}$ SIZE $_{\text {it }}+\beta_{3}$ LEV $_{\text {it }}+\beta_{4}$ INV $_{\text {it }}+\varepsilon_{\text {it }}$

$\mathbf{H}_{\mathbf{0}}$ : The manufacturing sector firms having higher compliance of corporate governance practices are not expected to have higher ROA.

$\mathbf{H}_{1}$ : The manufacturing sector firms having higher compliance of corporate governance practices are expected to have higher ROA.

Table 4: Estimation Results for ROA

\begin{tabular}{|c|c|c|c|}
\hline \multirow{2}{*}{$\begin{array}{c}\text { Dependent } \\
\text { variable }\end{array}$} & \multicolumn{3}{|c|}{ MODEL(1) } \\
\cline { 2 - 4 } ROA & Pooled Regression & $\begin{array}{c}\text { Fixed Effect Regression } \\
\text { Model } \\
\text { (FE) }\end{array}$ & $\begin{array}{c}\text { Random Effect } \\
\text { Regression Model } \\
\text { (RE) }\end{array}$ \\
\hline CGI & $(0.000489)$ & $(0.002523)$ & $(0.00343)$ \\
& $(0.007)$ & $(0.000)$ & $(0.005)$ \\
\hline SIZE & $(0.00132)$ & $(0.00728)$ & $(0.00899)$ \\
& $(0.000)$ & $(0.062)$ & $(0.000)$ \\
\hline LEV & $(-0.0097)$ & $(0.0068)$ & $(-0.0016)$ \\
& $(0.055)$ & $(0.381)$ & $(0.051)$ \\
\hline INV & $(-0.00155)$ & $(0.00291)$ & $(-0.01650)$ \\
& $(0.001)$ & $(0.000)$ & $(0.000)$ \\
\hline CONS & $(-0.00183)$ & $(0.0950)$ & $(0.00356)$ \\
& $(0.458)$ & $(0.007)$ & 0.4355 \\
\hline R & 0.4937 & 0.5215 & 16.50 \\
\hline F-Statistics & 15.10 & 12.60 & $(0.0000)$ \\
\hline \multicolumn{2}{|c|}{ Hausman Specification Test } \\
\hline Chi 2 & $(0.0000)$ & 36.44 & \\
Prob>chi2 & & 0.0000 & \\
\hline
\end{tabular}

The results given by pooled regression (FE \& RE) indicate that corporate governance and ROA has significant relationship as evident from value of F-statistics.

Hausman Specification Test results depicts thatRandom Effect regression model is better than fixed effect regression model. So the results given by RE regression estimation are more 
dependable.

The results for ROA and CGI relationship are in consistent with the results givens by (Coles, et al., 2001),(Joh, 2003) and (Javed \& Iqbal, 2010).

Results for model (1I)

$\begin{aligned} \text { PERF }_{\text {it }}=\beta+ & \beta_{1} \text { BOD }_{\text {it }}+\beta_{2} \text { OWN }_{\text {it }}+\beta_{3} \text { DISCL }_{\text {it }}+\beta_{4} \text { SIZE }_{\text {it }}+\beta_{5} \text { LEV Vit }_{\text {it }}+\beta_{6} \text { INV }_{\text {it }} \\ & +\varepsilon_{\text {it }}\end{aligned}$

$\mathbf{H}_{1 \mathbf{a}}$ :Board structure has significant relationship with ROA.

$\mathbf{H}_{1 \mathbf{b}}$ :Ownership structure has significant relationship with ROA.

$\mathbf{H}_{1 \mathbf{c}}$ : Transparency and disclosure has significant relationship with ROA.

Table 5: Estimation Results for ROA

\begin{tabular}{|c|c|c|c|}
\hline Dependent & & MODEL(1I) & \\
\hline ROA & $\begin{array}{c}\text { Pooled Regression } \\
\text { (OLS) }\end{array}$ & $\begin{array}{c}\text { Fixed Effect Regression } \\
\text { Model } \\
\text { (FE) }\end{array}$ & $\begin{array}{c}\text { Random Effect } \\
\text { Regression Model } \\
\text { (RE) }\end{array}$ \\
\hline BOD & $\begin{array}{c}0.000022 \\
(0.0290)\end{array}$ & $\begin{array}{c}0.0017059 \\
(0.036)\end{array}$ & $\begin{array}{c}.0006362 \\
(0.006) \\
\end{array}$ \\
\hline OWN & $\begin{array}{c}0.0006344 \\
(0.042)\end{array}$ & $\begin{array}{c}0.0009983 \\
(0.003)\end{array}$ & $\begin{array}{c}0.0001426 \\
(0.008)\end{array}$ \\
\hline DISCL & $\begin{array}{c}0.0017981 \\
(0.095)\end{array}$ & $\begin{array}{c}0.0046051 \\
(0.041)\end{array}$ & $\begin{array}{c}0.0025475 \\
(0.046)\end{array}$ \\
\hline SIZE & $\begin{array}{c}0.135246 \\
(0.000)\end{array}$ & $\begin{array}{c}0.1017486 \\
(0.017)\end{array}$ & $\begin{array}{c}0.1235652 \\
(0.000)\end{array}$ \\
\hline LEV & $\begin{array}{c}-0.0926089 \\
(0.074) \\
\end{array}$ & $\begin{array}{c}0.0713671 \\
(0.247)\end{array}$ & $\begin{array}{c}0.0964401 \\
(0.067)\end{array}$ \\
\hline INV & $\begin{array}{c}0.1595188 \\
(0.000)\end{array}$ & $\begin{array}{c}0.3058313 \\
(0.000)\end{array}$ & $\begin{array}{c}1.823644 \\
(0.000)\end{array}$ \\
\hline CONS & $\begin{array}{c}-.00670433 \\
(0.818) \\
\end{array}$ & $\begin{array}{c}-1.638542 \\
(0.024) \\
\end{array}$ & $\begin{array}{c}-.3635569 \\
(0.305) \\
\end{array}$ \\
\hline $\mathbf{R}^{2}$ & 0.2148 & 0.2633 & 0.1870 \\
\hline F-Statistics & $\begin{array}{c}3.79 \\
(0.0000) \\
\end{array}$ & $\begin{array}{c}3.93 \\
(0.002) \\
\end{array}$ & $\begin{array}{c}19.13 \\
(0.0000) \\
\end{array}$ \\
\hline & $\mathrm{Hz}$ & an Specification Test & \\
\hline $\begin{array}{c}\text { Chi } 2 \\
\text { Prob>chi2 }\end{array}$ & & $\begin{array}{c}125.32 \\
0.07610\end{array}$ & \\
\hline
\end{tabular}

Sub indices of board and ownership structure has positive and significant relationship with 


\section{Macrothink}

Journal of Public Administration and Governance

ISSN 2161-7104

2015, Vol. 5, No. 2

ROA but sub index of disclosure and transparency do not have significant relationship with firm performance as p- value this index is 0.095. Value of F-statistics shows that fitness of test is good. Coefficient of determination shows that change in ROA $21 \%$ is due to the good corporate governance practices. But this method is not reliable because it ignores the heterogeneity and panel nature of data.

Hausman Specification Test shows that the p-value is 0.0761 which is greater than 0.05 so we conclude that Fixed Effect regression model is better than Random Effect regression model. So the results given by FE regression estimation are more prudent.

The sub hypotheses $\mathrm{H}_{1 \mathrm{a}}, \mathrm{H}_{2 \mathrm{a}}$ and $\mathrm{H}_{3 \mathrm{a}}$ are accepted because these sub indices significantly have impact on firm performance.

Relationship of corporate governance and firm performance using ROE as performance indicator

PERF $_{\text {it }}=\beta+\beta_{1}$ CGI it $_{\text {it }}++\beta_{2}$ SIZE $_{\text {it }}+\beta_{3}$ LEV $_{\text {it }}+\beta_{4}$ INV $_{\text {it }}+\varepsilon_{\text {it }}$

$\mathbf{H}_{\mathbf{0}}$ : The manufacturing sector firms having higher compliance of corporate governance practices are not expected to have higher ROE.

$\mathbf{H}_{1}$ : The manufacturing sector firms having higher compliance of corporate governance practices are expected to have higher ROE.

Table 6: Estimation Results For ROE

\begin{tabular}{|c|c|c|c|}
\hline \multirow{2}{*}{$\begin{array}{c}\text { Dependent } \\
\text { variable } \\
\text { ROE }\end{array}$} & \multicolumn{3}{|c|}{ MODEL(1) } \\
\hline & $\begin{array}{c}\text { Pooled Regression } \\
\text { (OLS) }\end{array}$ & $\begin{array}{c}\text { Fixed Effect Regression } \\
\text { Model } \\
\text { (FE) }\end{array}$ & $\begin{array}{c}\text { Random Effect } \\
\text { Regression Model } \\
\text { (RE) }\end{array}$ \\
\hline CGI & $\begin{array}{c}(0.00475) \\
(0.005)\end{array}$ & $\begin{array}{c}(0.0059747) \\
(0.120)\end{array}$ & $\begin{array}{c}(0.0044085) \\
(0.024)\end{array}$ \\
\hline SIZE & $\begin{array}{c}(0.4179986) \\
(0.479)\end{array}$ & $\begin{array}{c}(0.689329) \\
(0.011)\end{array}$ & $\begin{array}{c}(0.3424655) \\
(0.568)\end{array}$ \\
\hline LEV & $\begin{array}{c}(0.4708687) \\
(0.551)\end{array}$ & $\begin{array}{c}(1.958564) \\
(0.116)\end{array}$ & $\begin{array}{c}(0.4152241) \\
(0.440)\end{array}$ \\
\hline CONS & $\begin{array}{c}(-0.8299692) \\
(0.853)\end{array}$ & $\begin{array}{l}(-7.3315) \\
(0.056)\end{array}$ & $\begin{array}{c}(-1.359538) \\
(0.777)\end{array}$ \\
\hline $\mathbf{R}^{2}$ & 0.6893 & 0.679 & 0.6864 \\
\hline F-Statistics & $\begin{array}{c}60.20 \\
(0.000)\end{array}$ & $\begin{array}{c}71.30 \\
(0.000)\end{array}$ & $\begin{array}{c}89.73 \\
(0.000)\end{array}$ \\
\hline \multicolumn{4}{|c|}{ Hausman Specification Test } \\
\hline $\begin{array}{c}\text { Chi } 2 \\
\text { Prob>chi2 }\end{array}$ & & $\begin{array}{c}6.87 \\
(0.2134) \\
\end{array}$ & \\
\hline
\end{tabular}




\section{Macrothink}

Journal of Public Administration and Governance

ISSN 2161-7104

2015, Vol. 5, No. 2

Hausman Specification Testshows that the p- value is 0.0000 which is less than 0.05 so we conclude that random effect regression model is better than fixed effect regression model. So the results given by RE regression estimation are more reliable.

\section{Results for model (1I)}

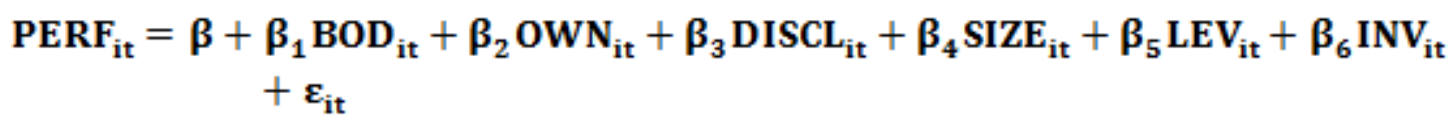

$\mathbf{H}_{\mathbf{1} \mathbf{a}}:$ Board structure has significant relationship with ROE.

$\mathbf{H}_{\mathbf{1 b}}$ :Ownership structure has significant relationship with ROE.

$\mathbf{H}_{1 \mathbf{c}}$ : Transparency and disclosure has significant relationship with ROE.

Table 7: Estimation results for ROE

\begin{tabular}{|c|c|c|c|}
\hline \multirow{2}{*}{$\begin{array}{c}\text { Dependent } \\
\text { variable }\end{array}$} & \multicolumn{3}{|c|}{ MODEL(II) } \\
\cline { 2 - 4 } ROE & Pooled Regression & $\begin{array}{c}\text { Fixed Effect Regression } \\
\text { Model } \\
\text { (FE) }\end{array}$ & $\begin{array}{c}\text { Random Effect } \\
\text { Regression Model } \\
\text { (RE) }\end{array}$ \\
\hline \multirow{2}{*}{ BOD } & $($ OLS) & 0.0017059 & 0.0035626 \\
& 0.0060148 & $(0.036)$ & $(0.007)$ \\
\hline OWN & $(0.079)$ & 0.0009983 & 0.0019471 \\
& 0.0023863 & $(0.394)$ & $(0.046)$ \\
\hline DISCL & $(0.008)$ & 0.0046051 & 0.0055953 \\
& 0.0068569 & 0.051 & $(0.008)$ \\
\hline SIZE & 0.046 & 0.1017486 & 0.3724034 \\
& 0.4338292 & $(0.017)$ & $(0.539)$ \\
\hline LEV & $(0.470)$ & 0.0713671 & 0.9504587 \\
& 0.2646304 & $(0.247)$ & $(0.711)$ \\
\hline INV & $(0.779)$ & 0.3058313 & 0.4268128 \\
& 0.4327486 & $(0.000)$ & $(0.601)$ \\
\hline R $^{2}$ & $(0.589)$ & 0.2633 & 0.4011 \\
\hline F-Statistics & 0.2116 & 2.68 & 0.81 \\
& 0.16 & $(0.002)$ & $(0.001)$ \\
\hline \multicolumn{2}{|c|}{ Hausman Specification Test } & \\
\hline Chi 2 & $(0.000)$ & 9.22 & $(0.0017)$ \\
Prob>chi2 & & & \\
\hline
\end{tabular}

Pooled regression results shown by OLS indicate that each sub index of corporate governance has considerable influence on firm performance as measured by ROE.

FE regression results integrates that significant and positive association exists between ROE and sub indices of ownership structure and board structure corporate governance. 


\section{Macrothink}

Journal of Public Administration and Governance

ISSN 2161-7104

2015, Vol. 5, No. 2

The results from RE regression specify that significant and positive association exists between ROE and sub index 1 and II board and ownership structure of corporate governance while positive but not significant association exist between ROE and sub index III i.e. disclosure and transparency.

Hausman Specification Test shows that the p- value is 0.1617 which is less than 0.05 so we conclude that random effect regression model is better than fixed effect regression model. So the results given by RE regression estimation are more prudent.

By rejecting Ho in favor of Random Effect Regression Model the results are concluded on basis of RE .The sub hypothesis $\mathbf{H}_{\mathbf{3 a}}$ is rejected but the hypotheses $\mathbf{H}_{\mathbf{1}}$ and $\mathbf{H}_{\mathbf{2}}$ are accepted because these sub indices significantly have impact on firm performance.

4.4.3 Relationship of corporate governance and firm performance using Tobin's $Q$ as performance indicator

PERF $_{\text {it }}=\beta+\beta_{1}$ CGI it $_{\text {it }}++\beta_{2} \operatorname{SIZE}_{\text {it }}+\beta_{3} \operatorname{LEV}_{\text {it }}+\beta_{4}$ INV $_{\text {it }}+\varepsilon_{\text {it }}$

$\mathbf{H}_{\mathbf{0}}$ : The manufacturing sector firms having higher compliance of corporate governance practices are not expected to have higher Tobin's Q.

$\mathbf{H}_{1}$ : The manufacturing sector firms having higher compliance of corporate governance practices are expected to have higher Tobin's Q.

Table 8: Estimation Results for Tobin's

\begin{tabular}{|c|c|c|c|}
\hline \multirow{2}{*}{$\begin{array}{c}\text { Dependent } \\
\text { variable } \\
\text { Tobin's Q }\end{array}$} & \multicolumn{3}{|c|}{ MODEL(1) } \\
\hline & $\begin{array}{c}\text { Pooled Regression } \\
\text { (OLS) }\end{array}$ & $\begin{array}{c}\text { Fixed Effect Regression } \\
\text { Model } \\
\text { (FE) }\end{array}$ & $\begin{array}{c}\text { Random Effect } \\
\text { Regression Model } \\
\text { (RE) }\end{array}$ \\
\hline CGI & $\begin{array}{c}0.0129853 \\
(0.124)\end{array}$ & $\begin{array}{c}0.0167806 \\
(0.228)\end{array}$ & $\begin{array}{c}0.0144357 \\
(0.167)\end{array}$ \\
\hline SIZE & $\begin{array}{c}0.5225105 \\
(0.018)\end{array}$ & $\begin{array}{c}0.241031 \\
(0.280)\end{array}$ & $\begin{array}{c}0.3641726 \\
(0.070)\end{array}$ \\
\hline LEV & $\begin{array}{c}-0.870028 \\
(0.012) \\
\end{array}$ & $\begin{array}{c}0.2593359 \\
(0.463)\end{array}$ & $\begin{array}{c}-.4893388 \\
(0.123) \\
\end{array}$ \\
\hline INV & $\begin{array}{c}0.4186462 \\
(0.151)\end{array}$ & $\begin{array}{c}0.6301885 \\
(0.126)\end{array}$ & $\begin{array}{c}0.4075128 \\
(0.181)\end{array}$ \\
\hline CONS & $\begin{array}{c}(0.5255294) \\
(0.750)\end{array}$ & $\begin{array}{c}(-4.641139) \\
(0.253) \\
\end{array}$ & $\begin{array}{c}(-1.0633) \\
(0.066)\end{array}$ \\
\hline $\mathbf{R}^{2}$ & 0.1505 & 0.0658 & 0.1531 \\
\hline F-Statistics & $\begin{array}{c}3.76 \\
(0.0002)\end{array}$ & $\begin{array}{c}4.82 \\
(0.0004)\end{array}$ & $\begin{array}{c}7.18 \\
(0.0006)\end{array}$ \\
\hline \multicolumn{4}{|c|}{ Hausman Specification Test } \\
\hline
\end{tabular}


Chi 2

32.83

Prob>chi2

$(0.005)$

RE regression results specify that significant association exists between Tobin's $Q$ and corporate governance. The probability value is 0.006 which is less than 0.05 so we reject $\mathrm{H}_{0}$ and conclude that with corporate governance practices the firm performance of the manufacturing companies will significantly enhances.

Hausman Specification Test shows that the p- value is 0.005 which is less than 0.05 so we conclude that random effect regression model is better than fixed effect regression model.

Results for model (1I)

$$
\begin{aligned}
\text { PERF }_{\text {it }}=\beta+ & \beta_{1} \text { BOD }_{\text {it }}+\beta_{2} \text { OWN }_{\text {it }}+\beta_{3} \text { DISCL }_{\text {it }}+\beta_{4} \text { SIZE }_{\text {it }}+\beta_{5} \text { LEV }_{\text {it }}+\beta_{6} \text { INV }_{\text {it }} \\
& +\varepsilon_{\text {it }}
\end{aligned}
$$

$\mathbf{H}_{1 \mathbf{a}}$ :Board structure has significant relationship with Tobin's Q.

$\mathbf{H}_{\mathbf{1 b}}$ :Ownership structure has significant relationship with Tobin's Q.

$\mathbf{H}_{1 \mathbf{c}}$ : Transparency and disclosure has significant relationship with Tobin's Q.

\begin{tabular}{|c|c|c|c|}
\hline \multirow{2}{*}{$\begin{array}{c}\text { Dependent } \\
\text { variable } \\
\text { Tobin's Q }\end{array}$} & \multicolumn{3}{|c|}{ MODEL(II) } \\
\hline & $\begin{array}{c}\text { Pooled Regression } \\
\text { (OLS) }\end{array}$ & $\begin{array}{c}\text { Fixed Effect Regression } \\
\text { Model } \\
\text { (FE) }\end{array}$ & $\begin{array}{c}\text { Random Effect } \\
\text { Regression Model } \\
\text { (RE) }\end{array}$ \\
\hline BOD & $\begin{array}{c}0.0016721 \\
(0.840)\end{array}$ & $\begin{array}{c}0.0082566 \\
(0.044)\end{array}$ & $\begin{array}{c}0.0076155 \\
(0.0389)\end{array}$ \\
\hline OWN & $\begin{array}{c}0.0036022 \\
(0.374) \\
\end{array}$ & $\begin{array}{c}0.0032419 \\
(0.639)\end{array}$ & $\begin{array}{c}0.0029239 \\
(0.559)\end{array}$ \\
\hline DISCL & $\begin{array}{c}0.010829 \\
(0.245)\end{array}$ & $\begin{array}{c}0.0077385 \\
(0.574)\end{array}$ & $\begin{array}{c}0.0078431 \\
(0.458)\end{array}$ \\
\hline SIZE & $\begin{array}{c}0.5234559 \\
(0.020)\end{array}$ & $\begin{array}{c}-0.2245875 \\
(0.363)\end{array}$ & $\begin{array}{c}-0.3378827 \\
(0.107) \\
\end{array}$ \\
\hline LEV & $\begin{array}{c}0.9055707 \\
0.010 \\
\end{array}$ & $\begin{array}{c}-0.2622657 \\
0.470 \\
\end{array}$ & $\begin{array}{c}-0.4756042 \\
0.137 \\
\end{array}$ \\
\hline INV & $\begin{array}{c}.393433 \\
0.183 \\
\end{array}$ & $\begin{array}{c}.5951313 \\
0.161 \\
\end{array}$ & $\begin{array}{c}.4002247 \\
0.206 \\
\end{array}$ \\
\hline CONS & $\begin{array}{c}.5191678 \\
0.791 \\
\end{array}$ & $\begin{array}{c}-4.674862 \\
0.269 \\
\end{array}$ & $\begin{array}{c}1.574254 \\
0.547 \\
\end{array}$ \\
\hline $\mathbf{R}^{2}$ & 0.2578 & 0.1688 & 0.4586 \\
\hline F-Statistics & $\begin{array}{c}2.59 \\
(0.000) \\
\end{array}$ & $\begin{array}{c}4.63 \\
(0.000) \\
\end{array}$ & $\begin{array}{c}7.17 \\
(0.000) \\
\end{array}$ \\
\hline
\end{tabular}

Table 9: Estimation Results for Tobin's Q 


\begin{tabular}{|c|c|}
\hline \multicolumn{2}{|c|}{ Hausman Specification Test } \\
\hline Chi 2 & 25.52 \\
Prob>chi2 & 0.008 \\
\hline
\end{tabular}

Pooled regression OLS indicate that all sub-indices of corporate governance and Tobin's Q has positive relationship as evident from value of coefficient but sub indices of ownership structure and disclosure and transparency do not have significant relationship with firm performance as p- value for both indices are 0.840 and 0.374 . But this method is not reliable because it ignores the heterogeneity and panel nature of data.

The results from RE regression specify that significant and association exists between Tobin's $\mathrm{Q}$ and sub index 1 board structure of corporate governance while positive but not significant association exist between Q and sub indices II and III of ownership structure and disclosure of transparency .

Hausman Specification Testshows that the p- value is 0.008 which is less than 0.05 so we conclude thatrandom effect regression model is better than fixed effect regression model.

These results specify that the board structure ofmanufacturingfirms is characterize by processing larger board with composition of independent and executive directors, have high frequency of board meeting with good effectiveness and ownership structure has ownership concentration, presence of larger block holders, family and managerial ownership is present but not in good proportion and the companies do not do complete disclosure in their annual reports. These results are consistent with study of (Mir \& Nishat, 2004),(Javed \& Iqbal, 2010) and (Love \& Klapper, 2002).

Relationship of Corporate Governance and External Finance

MODEL (3)

$\mathrm{EF}_{\mathrm{it}}=\beta+\beta_{1} \mathrm{CGI}_{\mathrm{it}}+\beta_{2} \mathrm{SIZE}_{\mathrm{it}}+\beta_{3} \mathrm{LEV}_{\mathrm{it}}+\beta_{4} \mathrm{INV}_{\text {it }}+\varepsilon_{\mathrm{it}}$

$\mathbf{H}_{\mathbf{0}}$ : The firms relying on external financing are not expected to have higher level of Corporate Governance Compliance

$\mathbf{H}_{2}$ : The firms relying on external financing are expected to have higher level of Corporate Governance. 
Table 10: Estimation results for $\mathrm{EF}$

\begin{tabular}{|c|c|c|c|}
\hline \multirow{2}{*}{$\begin{array}{c}\text { Dependent } \\
\text { variable } \\
\text { EF }\end{array}$} & \multicolumn{3}{|c|}{ MODEL(III) } \\
\cline { 2 - 4 } & Pooled Regression & $\begin{array}{c}\text { Fixed Effect Regression } \\
\text { Model } \\
\text { (FE) }\end{array}$ & $\begin{array}{c}\text { Random Effect } \\
\text { Regression Model } \\
\text { (RE) }\end{array}$ \\
\hline CGI & $(0.0105336)$ & $(0 . .0170479)$ & $(0.0154283)$ \\
& $(0.025)$ & $(0.042)$ & $(0.031)$ \\
\hline SIZE & $(0.0408575)$ & $(0.0223501)$ & $(0.0038)$ \\
& $(0.618)$ & $(0.435)$ & $(0.976)$ \\
\hline LEV & $(-0.5694526)$ & $(-0.1644548)$ & $(-0.2174122)$ \\
& $(0.042)$ & $(0.435)$ & $(0.271)$ \\
\hline INV & $(1.289904)$ & $(1.331598)$ & $(0.000)$ \\
& $(0.000)$ & $(0.000)$ & $(-5.113983)$ \\
\hline CONS & $(-4.231847)$ & $(-5.775661)$ & $(0.005)$ \\
& $(0.002)$ & $(0.019)$ & 0.3940 \\
\hline R $^{2}$ & 0.5780 & 0.3949 & 68.17 \\
\hline F-Statistics & 29.11 & 12.46 & $(0.000)$ \\
\hline & $(0.0000)$ & $(0.0000)$ & \\
\hline Chi 2 & & Hausman Specification Test & \\
\hline Prob>chi2 & & 0.87 & $(0.0000)$ \\
\hline
\end{tabular}

Random Effect Regression Model shows the probability value is 0.031 which is less than 0.05 so we reject $\mathrm{H}_{0}$ and conclude that the need of external finance of the manufacturing companies significantly dependent with corporate governance practices.

Hausman Specification Test shows that the p- value is 0.000 which is g than 0.05 so we conclude that random effect regression model is better than fixed effect regression model.

\section{Conclusions}

To empirically investigate the relationship of corporate governance and firm performance by Tobin's' Q, ROA, ROE of manufacturing sector companies a composite CGI was developed. The Comparative analysis of regression estimations pooled, fixed effect and random effect reported the extent to which the Pakistani firms adopted the corporate governance structures in accordance with the compliance of code of corporate governance considering the period from 2009 to 2013. The CGI score has positive and significant relationship with performance both in terms of accounting and market. The innermost concern of corporate governance is to serve the interest of the shareholders as well as stakeholders. This relationship shows that the manufacturing sector firms are performing well due to the adoption and focus on the implementation of corporate governance practices. The sun index I of board structure has positive and significant relationship with firm performance and cause enhancement in the value of ROA, ROE and Tobin's. This relationship entails the implementation of independent 
board structure, exact proportion of executive and non executive director, separation of chair of CEO, existence of CFO and effectiveness of board with larger size. The sub index II of ownership structure has positive and significant relationship in terms of ROA and ROE but this relation is insignificant for Tobin's Q. This is because Pakistani firms have higher concentration of ownership characterize with family control the results specify that there must be a balance between the structures of ownership, presence of block holder, controlling of power with controlling shareholder.

The sub index III of disclosure and transparency has positive and insignificant relationship in terms of Tobin's Q and ROE while this relation is significant for ROA. The Pakistani firms have not enough resources and grounds to do full disclosure. The results specify that the firm towards the proper disclosure of remuneration of auditor and director, audit related party transaction and audit related committee. The need of external finance is highly associated with CGI score. The firms having higher level of compliance of corporate governance have more sources to acquire external finance I $n$ terms of debt and equity.

\section{Limitations of the study}

The scope of this study is subject to limitation on the basis of sample size. Sample size is based on 58 companies listed in Karachi Stock Exchange. These companies were selected on the availability of data. So the results are unlikely to be generalized for all the population of the manufacturing sector. The sample size was very small which prohibited the in depth study about the relationships of variables. The findings obtained by taking large time span and large sample size for this study would be different. The time span of study includes the time period from 2009 to 2013 and data is taken from the annual report of the companies as the secondary source of data.

\section{References}

Gillan, S., \& Starks, L. (1998). A survey of shareholder activism: Motivation and empirical evidence. Contemporary Finance Digest, 2(3), 10-34.

Jenkinson, T., \& Mayer, C. (2012). The assessment: corporate governance and corporate control. Oxford review of economic Policy, 8(3), 1-10.

Johnson, R. A., \& Greening, D. W. (1999). The effects of corporate governance and institutional ownership types on corporate social performance.Academy of Management Journal, 42(5), 564-576.

Shleifer, A., \&Vishny, R. W. (1997).A survey of corporate governance.The Journal of Finance, 52(2), 737-783.

Van Den Berghe, L., \& De Ridder, L. (1999). International standardisation of good corporate governance: Best practices for the board of directors: Springer.

La Porta, R., Lopez-de-Silanes, F., Shleifer, A., \&Vishny, R. (2000). Investor protection and corporate governance.Journal of Financial Economics, 58(1), 3-27.

Keasey, K., Thompson, S., \& Wright, M. (2005). Corporate governance: accountability, 
enterprise and international comparisons: Wiley. com.

Su, D., \& He, X. (2012).Ownership structure, corporate governance and productive efficiency in China.Journal of Productivity Analysis, 38(3), 303-318.

Bokpin, G. A., \&Arko, A. C. (2009). Ownership structure, corporate governance and capital structure decisions of firms: Empirical evidence from Ghana. Studies in Economics and Finance, 26(4), 246-256.

Birdsall, K., Vyas, S., Khazaezadeh, N., \&Oteng - Ntim, E. (2009). Maternal obesity: a review of interventions. International journal of clinical practice, 63(3), 494-507.

Fama, \& Jensen, M. C. (1983).Agency Problems and Residual Claims.Journal of Law and Economics, 26: 2, 327-349.

Fama, E. F., \& Jensen, M. C. (1983).Separation of ownership and control.Journal of law and economics, 26(2), 301-325.

Antwi, S., \&Binfor, F. (2013). The Effect of Corporate Governance on Strategic Change in Financial Institutions: Evidence from Ghana. International Journal of Academic Research in Business and Social Sciences, 3, 159-179.

Lin, W.-C., \& Chang, S.-C.(2012). Corporate governance and the stock market reaction to new product announcements.Review of Quantitative Finance and Accounting, 39(2), 273-291.

Brickley, J. A., Coles, J. L., \& Terry, R. L. (1994).Outside directors and the adoption of poison pills.Journal of Financial Economics, 35(3), 371-390.

Rosenstein, S., \& Wyatt, J. G. (1990).Outside directors, board independence, and shareholder wealth.Journal of Financial Economics, 26(2), 175-191.

Xie, B., Davidson, W. N., \&DaDalt, P. J. (2003). Earnings management and corporate governance: the role of the board and the audit committee. Journal of Corporate Finance, 9(3), 295-316.

Yermack, D. (1996). Higher market valuation of companies with a small board of directors. Journal of Financial Economics, 40(2), 185-211.

Murphy, K., \& Jensen, M. (1998).Performance pay and top management incentives.

Brown, L. D., \&Caylor, M. (2010).L.(2009). Corporate governance and firm operating performance.Review of Quantitative Finance and Accounting, 32, 129-144.

Bauer, R., Frijns, B., Otten, R., \&Tourani-Rad, A. (2008). The impact of corporate governance on corporate performance: Evidence from Japan. Pacific-Basin Finance Journal, 16(3), 236-251.

Black, B. S., Jang, H., \& Kim, W. (2006). Does corporate governance predict firms' market values? Evidence from Korea.Journal of Law, Economics, and Organization, 22(2), 366-413. 


\section{Macrothink}

Journal of Public Administration and Governance ISSN 2161-7104 2015, Vol. 5, No. 2

Klein, Shapiro, \& Young.(2005). Corporate Governance, Family Ownership and Firm Value.Corporate Governance, 13, 112-213.

Hussain, S. H., \&Mallin, C. (2003). The dynamics of corporate governance in Bahrain: structure, responsibilities and operation of corporate boards. Corporate Governance: $A n$ International Review, 11(3), 249-261.

Dahya, J., Dimitrov, O., \& McConnell, J. J. (2008). Dominant shareholders, corporate boards, and corporate value: A cross-country analysis. Journal of Financial Economics, 87(1), 73-100.

Bai, C.-E., Liu, Q., Lu, J., Song, F. M., \& Zhang, J. (2006).An empirical study on corporate governance and market valuation in China.Frontiers of Economics in China, 1(1), 83-111

Claessens, S., Djankov, S., Fan, J. P., \& Lang, L. H. (2002). Disentangling the incentive and entrenchment effects of large shareholdings.The Journal of Finance, 57(6), 2741-2771.

Durnev, A., \& Kim, E. (2005). To steal or not to steal: Firm attributes, legal environment, and valuation. The Journal of Finance, 60(3), 1461-1493.

Iqbal, J., Kurose, Y., Canny, B., \& Clarke, I. J. (2006).Effects of central infusion of ghrelin on food intake and plasma levels of growth hormone, luteinizing hormone, prolactin, and cortisol secretion in sheep.Endocrinology, 147(1), 510-519.

Patrick, H. (2001). Corporate governance, ownership structure and financial crisis: Experience of East Asian countries. Paper presented at the KDIC International Financial Symposium.

Kiel, G. C., \& Nicholson, G. J. (2003). Board composition and corporate performance: how the Australian experience informs contrasting theories of corporate governance. Corporate Governance: An International Review, 11(3), 189-205.

Baysinger, B. D., \& Butler, H. N. (1985). Corporate governance and the board of directors: Performance effects of changes in board composition. Journal of Law, Economics, \& Organization, 1(1), 101-124.

Barnhart, S. W., Marr, M. W., \& Rosenstein, S. (1994). Firm performance and board composition: Some new evidence. Managerial and Decision Economics, 15(4), 329-340.

Mir, S. R., \&Nishat, M. (2004). Corporate Governance Structure and Firm Performance in Pakistan: An Empirical Study. Paper presented at the Second Annual Conference in Corporate Governance. Lahore University of Management Sciences, Lahore.

Love, I., \&Klapper, L. F. (2002).Corporate governance, investor protection, and performance in emerging markets.Research Working papers, 1(1), 1-39. 